\title{
Bulgaristan Göçmenlerinin Yaşadığı Selamlar Köyü Geleneksel Kadın Giysilerinin İncelenmesi
}

\author{
Investigation of Traditional Women Clothes in the Selamlar Village Lived by \\ Bulgaria Immigrants
}

\author{
Filiz DURSUN * - Gülden ABANOZ ** - Çiğdem DURSUN ${ }^{* * *}$
}

\begin{abstract}
ÖZET
Giyim; İnsanın var oluşuyla birlikte ortaya çıkmış uzun bir geleneğe dayanan, belirleyici ve iz bırakan bir olgudur. Önceleri insan vücudunu koruyan küçük deri ve bitki parçaları, zamanla, toplumsal ve kişisel değer yargılarının, kültürel ve ekonomik koşulların, teknolojinin biçimlendirdiği önemli bir kültürel öğeye dönüşmüştür. $\mathrm{Bu}$ kültürel öğe, savaşlar ve göçler neticesinde çeşitlenerek değişime uğramıştır. Türkiye, siyasi ve jeopolitik pozisyonuna bağlı olarak, tarih boyunca, çok sayıda göç hareketine sahne olmuş ülkelerden birdir. Türkiye'ye göç eden topluluklara bakıldığında; Tatar, Çerkez, Gürcü, Dağıstanlı, Çeçen, Suriyeli ve Bulgaristanlı Türklerin bulunduğu, bu göçmenlerin birçoğunun geleneklerini devam ettirdikleri ve özellikle Bulgaristan'dan göç eden Türklerin maddi kültür ve manevi değer öğesi olarak giyim-kuşam kültürlerini Türkiye'de hala yaşayıp, yaşatmaya çalıştıkları bilinmektedir. Araştırmanın amac1; Düzce ili Selamlar Köyüne yerleşmiş olan Balkan göçmeni Bulgaristan Türklerinin geleneksel kadın giysilerinin kumaş, kesim, model, renk, desen ve süsleme özelliklerini incelemek, geleneksel giysileri tanımak, tanıtmak ve gelecek kuşaklara aktarılmasını sağlamaktır.
\end{abstract}

Anahtar Kelimeler: Muhacir, Bulgaristan Göçmeni, Urba, İç Göynek, Ferace

\begin{abstract}
Clothing; It is a fact that is based on a long tradition that has emerged with the existence of man, and is a determinant and a trace. Small leather and plant parts that previously protected the human body have evolved into an important cultural element shaped by social and personal value judgments, cultural and economic conditions, and technology. This cultural element has been transformed and diversified as a result of wars and migrations. Turkey, depending on the political and geopolitical position, throughout history, has been the scene of a large number of countries from migration. Considering the community who migrated to Turkey; Tatars, Circassians, Georgians, Daghestani, Chechen, Syrian and Bulgarian where the Turks, they continued the traditions of many of these immigrants, and especially the Turks who emigrated from Bulgaria material culture and spiritual values of items as clothing of cultures still living in Turkey are known to try to keep alive. Purpose of the research; The aim of this study is to examine the fabric, cut, pattern, color, pattern and ornamentation features of Balkan immigrant Bulgarian Turks who are settled in Selamlar Village of Düzce province, to recognize and introduce traditional woman clothes and to transfer them to future generations.
\end{abstract}

Keywords: Muhajir, Bulgaria Immigrant, Urba, Iç Göynek, Ferace

\section{Giriş}

\footnotetext{
* Dr. Öğrt. Üyesi, Düzce Üniversitesi, Düzce Meslek Yüksekokulu, Moda Tasarım Programı, ORCID: orcid.org / 0000-0002-13409062, filizdursun@duzce.edu.tr.

** Öğr. Gör., Düzce Üniversitesi, Düzce Meslek Yüksekokulu, Moda Tasarım Programı, ORCID: orcid.org/ 0000-0002-4233-8830, guldenabanoz@duzce.edu.tr.

*** Öğr. Gör., Düzce Üniversitesi, Düzce Meslek Yüksekokulu, Moda Tasarım Programı, ORCID: orcid.org / 0000-0003-1845-7837, cigdemdursun@duzce.edu.tr.
} 
Giyim, insan vücuduna giyilen parçaların bütününden oluşan takım şeklinde tanımlanmaktadır (Werner, 1998:92). İnsanın var oluşuyla birlikte ortaya çıkmış olan uzun bir geleneğe dayanan giyim, belirleyici ve iz bırakan bir olgudur. Zaman içerisinde, insan vücudunu koruyan ve örten küçük deri ve bitki parçalarından, toplumsal ve kişisel değer yargılarının, kültürel ve ekonomik koşulların, teknolojinin biçimlendirdiği önemli bir kültürel ögeye dönüşmüş aynı zamanda da toplumları, insanları simgeleyen özgün bir hal almıştır (Köseoğlu, 1997:33). İnsan bedenini örten giysi, aksesuar makyaj ve bunları kullanma biçimi olan giyim; coğrafi koşullar, cinsiyet, yaşam tarzı ve kültür etkisi ile tarih boyu değişime uğramıştır. Kültür; geleneksel giyim tarzına da yansımış, hiyerarşik yapı, ekonomik durum, toplumsal statü, meslekler ve uğraşı alanları giyim tarzını belirleyici olmuştur (Türkoğlu, 2002:22). Sürür'e (1983) göre giyim, maddi kültür öğesi olarak geleneksel yaşam biçimleri arasında topluluğa ait olmayı simgeleyen manevi değerler öğesi olarak, topluluğa ait olma duygusunu da güçlendirerek sosyal güvenlik ve dayanışmayı da pekiştiren bir olgudur (Sürür, 1983:14). Bu özellikleri ile giyim; toplumları ve coğrafyaları inceleme aşamasında son derece önemli bir hâl almıştır. Türk kültürü içinde yer alan giyim kuşama ait özellik ve kaynakların varlığı Orta Asya'ya kadar uzanmaktadır. Tarih boyunca, ekonomik, sosyal, kültürel kimliğinden dolayı çekim merkezi haline gelmiş olan Anadolu: kitlesel göç dalgaları, Osmanlı Devleti'nin ve sonrasında da Türkiye Cumhuriyeti'nin toplumsal, etnik ve kültürel yapısını büyük ölçüde etkilemiştir. Bu sebeptendir ki; Türk giyim kuşamının, milletimizin uzun tarihi gelişimini, yayıldığ 1 geniş coğrafi alanı, etkileşim halinde olduğu kültürleri ve değiştirdiği inanç sistemlerini göz önünde tutarak değerlendirilmesi gerekir. Çünkü millî giyim kuşam millî kimliğin bir parçasıdır (Bakır, 1999:1-4). Milletleri sağlam temellere oturtan en önemli değerlerden birisi de giyinme kültürüdür (Sevin, 1973:1-4). Bu sebeptendir ki giyim kuşam Türk toplumunda geleneksel değerleri yansıtan önemli bir olgudur (Ayhan, 2013:1-13). Her dönemde çeşitli etkenlerin sebep olduğu sonuçlar doğrultusunda birbirinden ayrı özellikte millî ve yöresel giyimler oluşmuştur (Nas, vd. 2011: 246). Geleneksel kıyafetler kültürel mirasın önemli bir yönünü temsil eder, çünkü bu mirasın tarihi, medeniyeti ve kimliğinin bileşenlerinin temel bir parçası olan gelenek ve izleri ile gurur duyan her millet için önemli bir kaynaktır (Alajaji, 2012:516).

Anadolu'ya göç eden Türk toplumları inanç, örf, adet ve geleneklerinin yanı sıra giyim kuşam geleneklerini de yeni yurtlarına taşımışlardır. Anadolu Türkü'nün geldiği yöreden getirdiği kültür varlıkları yeni yurdun alışkanlıkları, iklim, doğa koşulları, din etkisi, devlet ferman ve emirleri ile şekillenmiştir (Görgünay Kırzıŏlu, 1988: 41-44). Anadolu'da yörelere özgü benimsenen ve kullanılan geleneksel giysiler, değişik süsleme özelliklerine sahiptir. Kadın giysilerinin biçimi, renkleri, motifleri ve güzelliği Anadolu insanının hayata bakışını yansıtır. Kadın giyim-kuşamı başa, bedene, ayağa giyilen giysiler, süslemeleri ve takıları ile bütünlük oluşturur (Tansuğ, 1997:23). Dünyanın her yerinde olduğu gibi ne yazık ki ülkemizde de sadece kırsal kesimde ve taşrada yaşamakta olan kadınlarımızdan bazıları yörelerine özgü olan bu millî kıyafetlerini muhafaza etmektedirler (Yener, 1955:24). Bunun sebepleri olarak, kentleşme, teknolojinin gelişmesi ile modernleşme, geçim sıkıntıları ve göçler sayılabilir.

Bir kişi veya grubun uluslararası bir sınırı geçmesi veya bir devlet içinde yer değiştirmesi şeklinde tanımlanan göç, insanlık tarihi kadar eski bir olgudur (Bayraktar, 2014; 196). Göç; toplumu sosyal, ekonomik, politik, kültürel, sağlık vb. bileşenleriyle etkileyen; kişileri yeni bir topluluğa götüren, doğal, iktisadi, siyasi ve benzeri mecburiyetler ile yaşadığ sağlama sorunlarıyla karşı karşıya bırakan bir "yer değiştirme” hareketidir (Arafat, 2000:33-43). Bu yer değiştirme eylemi, bazen gönüllülük esasına dayanırken bazen de şartlar doğrultusunda zorunlu şekilde meydana gelmektedir (Bayraktar, 2014; 196).

Türkiye tarihinde göçün önemli bir yeri vardır. Türkiye yıllardır yurtdışına işgücü ve yetişmiş, eleman göçü verdiği gibi, savaş, siyasi ve ekonomik sorunların etkisiyle Türk ve/veya Müslümanların yoğun bir şekilde göç ettiği ülke konumundadır. Tarihsel verilere bakıldığında, Osmanlı'nın genişleme döneminde Anadolu'dan Balkanlara yönelen göçün, 1800'lerin sonlarından itibaren tersine dönmüş, olduğu görülmektedir (Parla, 2007:157-181). 1877-1878 Osmanlı Rus Savaşı sonrası Osmanlı Devleti'nin Rumeli topraklarındaki hâkimiyetini kaybetmesiyle birlikte Bulgaristan Türkleri için 
oldukça zor günlerin başladığı bilinmektedir. 93 Harbi Türkiye'nin sadece Bulgaristan'dan değil diğer Balkan ülkelerinden de yoğun nüfus aldığı bir süreci başlatmıştır (Korkmaz-Öztürk 2017:269). Balkanlar'dan Türkiye'ye yoğun bir göçmen akışının nedenlerinin başında Sovyet dönemi maruz kaldıkları baskıların son bulmayışı, ortak değeri ve temel unsuru bakımından sahip oldukları kültürün Türkiye'deki kültürle yakın olması ve Türkiye' yi anavatan olarak görmeleri gibi sebepler de yaşanan göçü tetiklemiştir (Ünal-Demir 2009:392).

Bulgaristan örneği, sadece milliyetçilik açısından değil, asimilasyon, zorunlu göç ve bu göçe nelerin sebep olduğunun daha iyi anlaşılması için önemlidir (Korkmaz-Öztürk 2017:269). Bulgaristan'da Türklerin dini yaşamına yapılan müdahaleler 1957-1958 yıllarından itibaren şiddetlenmiş olmakla birlikte bu dönemden itibaren Türk kadınlarının ferace ve çarşaf giymeleri şiddet yoluyla engellenmiş İslamiyet'e dair kara propaganda artmıştır (Cebeci, 1970: 209-210). Asimilasyon ve göçe zorlamak gibi politikalarla karsı karsıya kalan Bulgaristan Türkleri kademeli bir şekilde Türkiye'ye göç etmişlerdir. En büyük Türk azınlığın yer aldığı Bulgaristan topraklarından anavatana göç hemen hemen yüz yıl sürmüştür (Korkmaz-Öztürk 2017:279). Balkanlardan gelerek ülkemize yerleşmiş tüm göçmenlere genel olarak Balkan göçmeni ve muhacir (macır) denilmekle birlikte, geldikleri bölgeye göre de isimlendirilmektedirler.

Balkanlardan Türkiye'ye göç eden Bulgaristan Türkleri çoğunlukla Marmara Bölgesi olmakla birlikte, yoğunlukta İstanbul, Bursa, İzmir, Tekirdağ ve Kırklareli olmak üzere çeşitli illere yerleştirilmişlerdir (Korkmaz-Öztürk 2017:279). Anadolu'nun çeşitli yerlerine yerleşen göçmenlerin bir kısmı da Düzce'nin çeşitli köylerine yerleşmişlerdir. Düzce'nin Gümüşova ilçesine bağlı olan Selamlar köyü de göç almış olan bu köylerden biridir. Selamlar; Düzce merkeze 18 km uzaklıkta bulunan D-100 karayolu üzerinde konumlanmış sakin huzurlu köylerden biridir. 300 haneli 900 nüfusa sahip olan köyün ilk kuran İbrahim Ağa ve beraberindekiler (9 hane) Bulgaristan göçmenidir. Ulu Önder Mustafa Kemal Atatürk, Ankara'dan İstanbul'a giderken Selamlar Köyü’nde (eski adıyla İbrahimağa Köyü) Osmanlı döneminden kalan 200 yıllık çeşmenin önünde oturmuş, köylünün sorunları dinledikten sonra ayran içerek dinlenmiştir. Köylülerden o yıllarda 7-8 yaşlarında olan Fatma Öztürk atamıza ayran ikram etmiştir. Mustafa Kemal Atatürk o gün köyün adını Selamlar olarak değiştirmiştir. O gün yani 18 Temmuz 1934 yılında köyün kaderi baştan yazılmıştır. İlki 1981 yılında yapılmış olan ve her yıl geleneksel olarak kutlanan 18 Temmuz Atatürk'ü anma etkinlikleri, halk arasında ayran bayramı olarak isimlendirilirken bu kutlamalara devlet büyükleri ve vatandaşlar katılmaktadır. Ayrıca bu etkinliklerde Devlet büyükleri Atatürk Müzesi'ndeki anı defterini imzalayarak düşüncelerini aktarmaktadır. Atatürk resimleri, Atatürk'e ayran yapılan ahşap yayık ve geleneksel kıyafetlerin sergilendiği müze, Selamlar köyü halkının geleneklerine ve değerlerine ne kadar bağlı olduklarını ortaya koymaktadır (Anonim, 2018).

Selamlar köyünde Bulgaristan göçmenleri halk arasında muhacir diye tanımlansa da aslında Türk olduklarını, dedelerinin Bulgaristan'dan göç ettiklerini, 90 muhaciri olduklarını ifade etmektedirler. Avrupa'da kargaşalar başlayınca insanlar çoluk çocuğuyla Türkiye'ye göç etmek zorunda kalmışlardır: "Burya (buraya) annem kocaya geliyor. Burda (burada) yetişiyorum. Bize muhacir diyorlar ama muhacir diye bir şey yok. Biz Türk'üz. Büyüklerimiz Bulgaristan'dan buraya göç etmişler. 90 muhaciri diyorlar. Demek ki bu köy yüz yirmi yıl olmuş kurulall. Avrupa'da kargaşalar başlayınca akıllı insanlar doldurmuş çoluk çocuğu buraya Türkiye’ye akın etmişler." (Kaynak Kişi; Tekin, 2012).

Bulgaristan'dan göçen Türkler örf, adet, gelenek, göreneklerini ve giyim kültürlerini Türkiye de yaşayıp yaşatmış ve yaşatmaya da devam etmektedir. Giyim kültürü, toplumların sosyal ve kültürel yapılarını barındıran özellikler taşıması bakımından birer etiket mahiyetindedir. Giysilerinde kullandıkları farklı malzeme ve süsleme özellikleri açısından kendilerine özgü giyim kültürlerini oluşturmuş ve yansitmışlardır.

Geleneksel kıyafetlerden şalvar; kırsal kesimlerde halen günlük giysi olarak kullanılmasına rağmen şehirlerde modanın ve şehir yaşantısının modernliğine yenilmiştir yalnızca örf, âdet, gelenek ve görenekleri sürdürmek amacıyla özel günlerde giyilmektedir (Fidan, 2012:17). Şalvarlarda mutlaka 
uçkur kullanılmaktadır. Uçkur; iç donu, çakşır, şalvar ve potur gibi belden aşağı giyilen giysileri belde tutmaya yarayan bir kuşaktır (Özel, 1992: 20). Anadolu kadınının vazgeçemediği şalvarın; model ve dikilişlerine göre değişik şekillerde adlandırıldığı bilinmektedir. Anadolu'nun hemen her bölgesinde kullanılan ve değişik özellikler gösteren şalvarlara bölgeden bölgeye, yöreden yöreye değişik isimler verilmektedir. Ayaklı, köncek, toptan, şalvar, paçalı don, tokurcum, çatal don bunlardan birkaçıdır. İzmir'de "şalvar", Eskişehir'de "dattiri", İç Anadolu'da "don çağşır", "çintiyan", Antalya'da don şalvar, Sinop'ta paça, dizlik, Adana şalvarı, Ege'de topan don, köncek, gökdon, tuman denilmektedir (Aydın, 2011: 8). Yelek; hava alacak surette kolsuz ve önü açık, eteği bele kadar kısa olup mintan üstüne ve ceket, salta, cepken altına giyilen giysinin adıdır. Yeleğin özelliği iki ön parçasının kumaş veya deri olup sırtı örten arka parçasının astar bezinden yapılmış olmasıdır. Eskiden kadınlar ipekli kumaşlardan ve işlemeler ile süslü diş yelekler giymişlerdir (Koçu, 1969: 242). Çember (Çenber); Boyun ve alına bağlanan yemeni olarak tanımlanmaktadır. Çenber, Cumhuriyet devrindeki kıyafet inkılabına kadar yüzyıllar boyunca erkekler, esnaf tabakası ve esnafin da ayak takımı tarafindan kullanılmıştır. Eskiden "destimal” ve "çevre” denilen dört köşe kare şeklinde mendile göre çok büyük olmayan yazma nakışlarla süslenirdi Çorab (Çorap); Ayağa giyilen örme şeydir. Kadın ve erkek çorabı olarak ikiye, ipliğin cinsine göre üçe ayrılır, yün veya tiftik çorap, pamuk ipliğinden örülmüş tire çorap, ipek çorap gibi çeşitleri bulunmaktadır (Koçu, 1967: 70). Ferece (Ferace); başı-saçları örten "yaşmak" ile tamamlanan bir üstlüktür. Feracede yaka, bu üstlügün bir ikinci parçası sayılacak kadar geniş ve omuzlardan sırttan yere dökülecek kadar büyüktür. Yaşmak ile birlikte Ferace Türk kadının eski sokak kıyafeti olarak bilinmektedir (Koçu, 1967: 78-79). Daha çok Osmanlılar 'da kullanılan bu dış kıyafet, Arapça 'da "açmak, yarmak; ferahlatmak" manasındaki ferc mastarından gelen kelimenin aslı fereciyye olup "önü açık ferah elbise" demektir. Feracenin giyim kuşam literatüründe üç ayrı elbise türünün adı olduğu görülür: Kadınların sokakta yaşmakla giydikleri üst elbisesi: ilim adamlarının giydikleri çok geniş ve bol, kolları yırtmaçlı bir çeşit cübbe biniş; Mevleviler 'in giydiği uzun hırka. Bu üç kıyafetten en eski olanı Mevlevi feracesidir ve Mevlana'nın anlattığı hikâyeye göre iç sıkıntısına uğrayan bir sufinin elbisesinin önünü yırtıp ferahlamasıyla ortaya çıkmış ve ondan sonra artık ferahlık anlamına gelen bu isimle anılmıştır (İslam Ansiklopedisi,1995:349). Futa: toplum hayatında yüzyıllar boyunca iş yaparken bele bağlanan, bütün esnafın ve zanaat erbabının müşterek kutsal bir maskotu, bir hüner, ehliyet, uğur, sıhhat alameti ve tılsımı bilinmiştir. Futalar bir zemin rengi üzerine mutlaka çubuklu ve çubuk kafesli olarak dokunmaktadır (Koçu, 1967: 119). İç göynek; doğrusu gömlektir, gön deri, ten anlamındadır. Çıplak tene giyilen şey demektir. Genellikle kadınların kullandığı ham ipekten ince bürümcük, biraz kalını erkekler için yapılmaktadır. Ham ipekten pek az miktarda keten ipliği katılarak dokunan yazlık eski güzel bir kumaşımız olan bürümcükten yapılan ten üzerine giyilen iç gömleğidir (Koçu, 1967: 48). Gocuk: kollu genişçe devrik yakalı ve beden kesimi diz kapağından aşağı doğru uzun olan, çoğunlukla koyun postundan yapılan kürkün adı olarak bilinmektedir (Koçu, 1967: 125). Yemeni (Başörtüsü): Üzerine el kalıpları ile çiçek desenli süs motifleri basılmış büyükçe bir tülbent bezin adıdır ve kadınlar tarafından etrafına oya yapılıp, süslenerek başa bağlanmaktadır (Koçu, 1967: 246).

Araştırmanın amacı; sandıklar ve bohçalarda ki geleneksel (yöresel) giysilerin kumaş, renk, desen, süsleme, model ve kesim özelliklerini inceleyerek, gün yüzüne çıkartmak, kültür varlıklarımızdan olan geleneksel giysileri tanımak, tanıtmak ve gelecek nesillere aktarılmasını sağlamaktır. Düzce'de Halk Edebiyatı, İnanışlar, Geleneksel Giyim ve Mimari isimli Bilimsel Araştırma Projesi kapsamında yapılan bu çalışmada, Düzce ili Selamlar Köyünde (Bulgaristan göçmeni, Muhacir Köyü) bulunan geleneksel kadın kıyafetlerinden üst ve iç giysileri incelenmiştir. Giysilerin incelenmesinde, gözlem fişleri doldurulmuş, giysilerde kullanılan malzeme, renk, model, kesim, dikim, astar ve süsleme özellikleri belirlenmiştir. Giysilerin farklı açılardan fotoğrafları çekilerek görsel hâle getirilmiştir.

\section{Geleneksel Kıyafetler}

\subsection{Urba 1}

Pembe şalvar ile birlikte bürümcük iç göynek üstüne yelek ile birlikte veya ayrı olarak giyilen bir özel gün giysisidir. Gelinliğin üst parçası olarak kullanılırdı. 72 yıllıktır (Kaynak Kişi; Aydın, 2012). 


\section{Al-Farabi International Journal on Social Sciences}

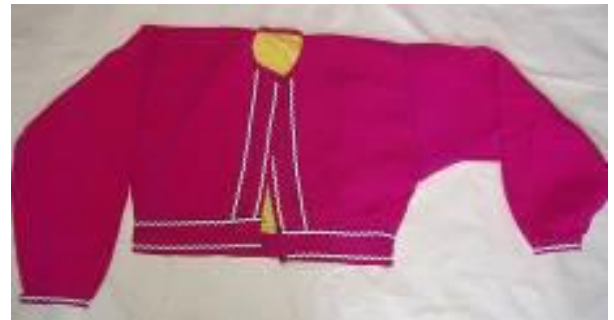

Resim 1. Urba (a) Önden görünüm.

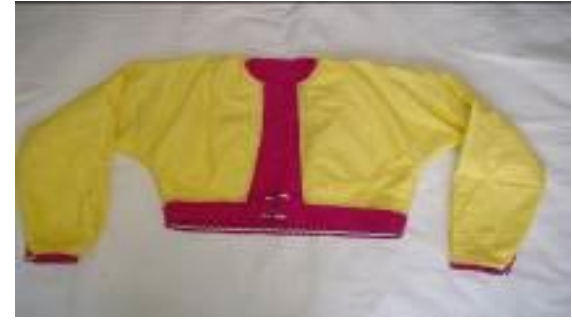

Urba (b) Astar görünümü.

Kumaş olarak pembe Mariken (ipek), astar olarak sarı pamuklu kumaş, siyah kurdele, sim sutaşı, siyah düğme kullanılmıştır. Boyu göğüs altında, sıfır yakalı, uzun oyuntusuz takma kollu, sıfir kapama, kemerli, kol ucu ve yaka kenarı biye ile temizlenmiş, kol ucu yırtmaçlı, göğüs altından pilili, beş adet birit ilik ve düğmeli, astarı ise; kuşlu japone kollu çalışılmıştır. Sarı pamuklu kumaş kullanılarak, astar makinede dikilerek, elde bedene tutturulmuştur. Urbanın süslemesinde; siyah kurdele üstüne sim sutaşı sabitlendikten sonra giysiye (makinede) dikilmiştir ve ön ortasına, kemere (makine dikişi ile) su şeklinde üçgen kapitone dikişi yapılmıştır.

\subsection{Urba 2}

Pembe şalvar ile birlikte bürümcük iç göynek üstüne yelek ile birlikte veya ayrı olarak giyilen bir özel gün giysisidir. Gelinliğin üst parçası olarak kullanılırdı (Kaynak Kişi; Aydın, 2012).

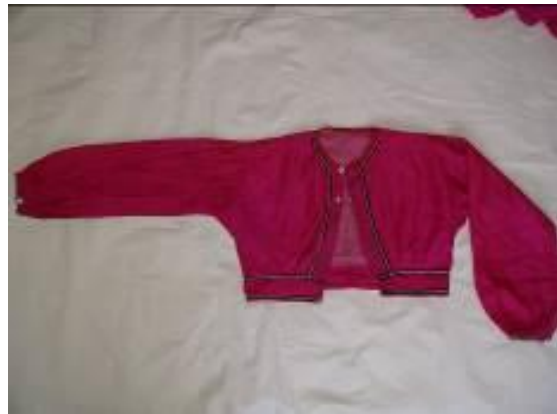

Resim 2. Urba (a) ön görünüm.

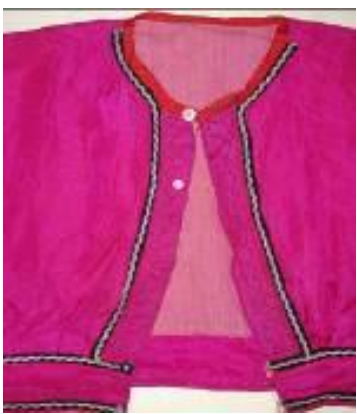

(b) Ön detay görünüm.

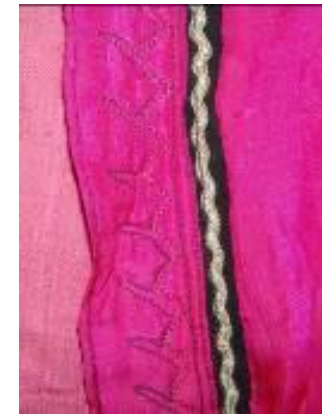

(c) Süsleme detay görünümü.

Kumaş olarak pembe Mariken (ipek), astar olarak pembe pamuklu kumaş, siyah kurdele, sim sutaşı, beyaz ve siyah düğme, siyah ve açı pembe dikiş ipliği kullanılmıştır. Boyu göğüs altında, uzun oyuntusuz takma kollu, sıfır yaka ve sıfır kapama, kemerli çalışılmıştır. Kol ucu ve yaka kenarı biye ile temizlenmiştir. Kol ucu yırtmaçlı ve gögüs altından pililidir. İki adet bedende, iki adet kemerde olmak üzere dört adet birit ilik çalışılmış ve düğme dikilmiştir. Astarı pembe pamuklu mermerşahi kumaş kullanılarak kuşlu japone kollu çalışılmıştır. Makine ve elde oyulgama dikiş tekniği kullanılarak dikilmiştir. Astar; yaka, kol ucu biyesi, kemer dikişi içine alınarak bedene tutturulmuştur. Urbanın süslemesinde; siyah kurdele üstüne sim sutaşı yerleştirilmiş sonra giysiye dikilerek sabitlenmiş ve ön bedende ön ortasına kemere makine dikişi ile su şeklinde kapitone dikişi yapılmıştır.

İncelenen iki urba da pembe renkli olmakla birlikte, tüm özellikleri açısından büyük benzerlik taşımaktadırlar. Bununla birlikte, Koca ve Komanlar (2019) “İzmit Balkan Kültür Evi’nde Sergilenen Bulgaristan Göçmeni Kadın Halk Giyim Kuşamı” adında ki çalışmalarında, Urbayı cepken olarak isimlendirmişlerdir. İncelendikleri iç göynek üzerine giyilen cepken (urba), kiremit kırmızısı renginde, ipek saten kumaştan, mavi beyaz renkte çizgili ince pamuklu kumaş, ile astarlanmıştır. Rengi, boyu ve korsajı dışında, diğer özellikleri benzerlik göstermektedir (Koca-Komanlar 2019: 936). Abanoz ve diğerlerinin (2016) "Düzce İli Hasanağa Köyü (Muhacir) Geleneksel Kadın 
Giysilerinin İncelenmesi” isimli çalışmalarında inceledikleri iki urba ile de bir urbanın rengi dışında, aynı özellikleri taşımaktadır (Abanoz, vd. 2016: 204).

\subsection{Yelek}

Pembe şalvar ile birlikte bürümcük gömlek üstüne giyilir ve gelinliğin (özel gün giysisi) üst parças1 olarak urba ile birlikte veya ayrı olarak kullanılırdı. 72 yıllıktır (Kaynak Kişi: Şahin, 2012).

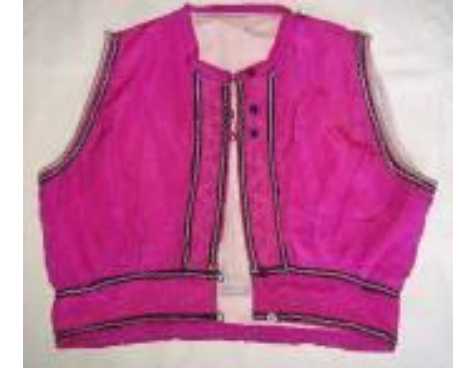

Resim 3. Yelek (a) Ön görünüm.

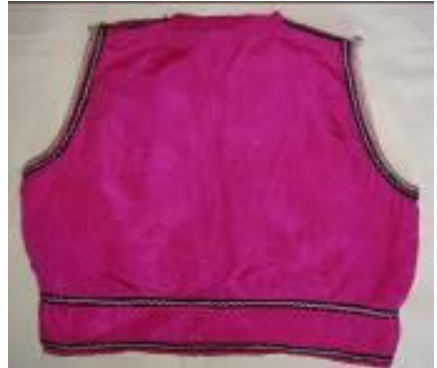

(b)Arka görünüm.

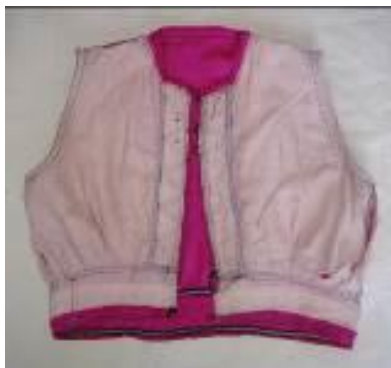

(c) Astar görünümü.

Yelek de pembe ipek (Mariken), astar da krem renkli mermerşahi kumaş, süslemesinde siyah kurdele, sim sutaşı, balıksırtı harç, siyah ve beyaz dikiş ipliği, dört adet siyah ve bir adet beyaz düğme kullanılmıştır. Yeleğin boyu göğüs altında ve sıfır yakalıdır, yaka biye ile temizlenmiştir. Sıfır kapama, kemerli, üç adet bedende, iki adet kemerde birit ilik-düğmelidir. Bedene dört adet pili ile oturtulmuştur. Makine ve elde oyulgama dikişi ile dikilmiştir. Krem renkli pamuklu mermerşahi kumaş makinede dikilerek yelekle birleştirilmiş, süslemesi daha sonra yapılmıştır. Ön, kemer ve kol oyuntusunda siyah şerit kumaş üzerine simli sutaşı, kol oyuntusu çevresine balıksırtı harç el ile tutturulmuştur. Beyaz renk iplik ile ön ortası kenarlarına çift sıra zikzak kapitone dikişi çekilerek süslemesi tamamlanmıștır.

Koca ve Komanlar (2019) çalışmalarında inceledikleri "fermene" adı verilmiş olan yelek; ince hâkim yakalı, önü boydan açık ve sarı simli ipliklerle işlenmiş, bel hizasında, fuşya rengi pamuklu kumaştan yapılmıştır. Hâkim yakanın içi ve klapası mor renkte pamuklu dokuma ile kaplanmış, bedeni ise Amerikan bezi ile astarlanmıştır. Yelek ve astarın parçaları makine ile birleștirilmesine rağmen, astarın bedene tutturulması elde baskı dikişi ile yapılmıştır (Koca-Komanlar 2019: 938). Yaka, boy, renk ve süsleme özellikleri farklı olmakla birlikte, dikiş ve astarlama tekniklerinin benzer olduğu saptanmıştır. Abanoz ve diğerlerinin (2016) çalışmasındaki yelek ile birebir aynı olduğu belirlenmiştir (Abanoz, vd. 2016: 203-204).

\section{4. İç göynek}

Yeleğin altına ve şalvarın üstüne giyilir, iç giysisi olarak kullanırdı. Bürümcük ve buruşuk isimleriyle de anılmaktadır. 78 yıllıktır (Kaynak Kişi: Aydın, 2012).

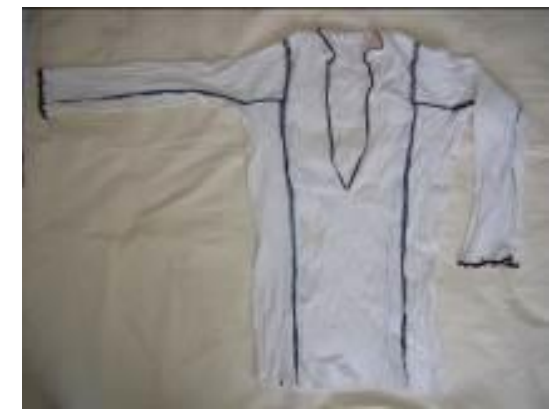

Resim 4. İç göynek (a) Ön görünüm.

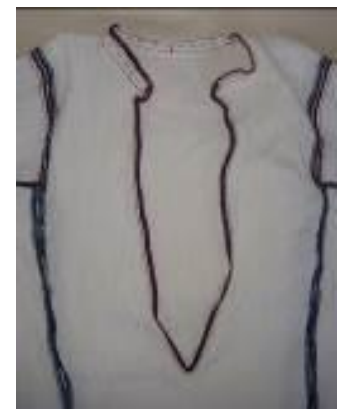

(b) Yaka yırtmaç detay.

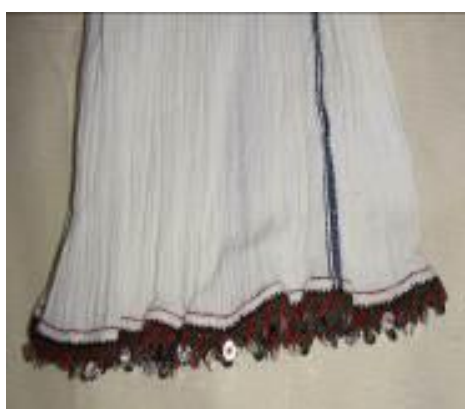

(c) Kol süsleme detay görünümü. 
Pamuklu krem renginde, bezayağı dar dokuma kumaş, süslemesinde mavi ve kırmızı ip ve metal pul, siyah, kırmızı dikiş ipliği kullanılmıştır. Sıfır yakalı, yaka biyesi $1 \mathrm{~cm}$ ön ortasında derin yaka yırtmacı olan, kol bedenden çıkan, kare takma kolludur. Dar dokuma olduğu için beden ve kollar, ön-arka ve yanlar olmak üzere dört parçadan çalışılmıştır. Makinede ve elde çırpma dikişi ile dikilmiştir. Yaka kenarı, yaka yırtmacı ve kol ucu iğne oyalıdır. Kol ucuna metal pul ilaveleri yapılarak süsleme zenginleştirilmiştir.

Abanoz ve diğerlerinin (2013) çalışmasındaki iç göynek ile aynı özellikleri göstermektedir (Abanoz, vd. 2013: 80-81).
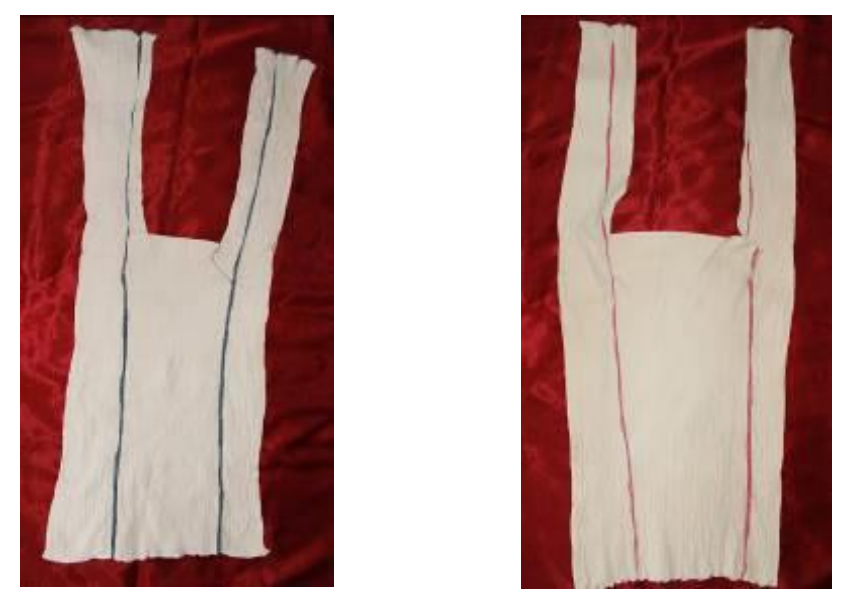

Resim 5. Yaka oyuntusu açılmamış (kullanılmamış) iç göynek ön ve arka görünümü.

İki göynekte kumaş, dikim ve model olarak aynı özelliktedir. Resim 5'teki örnek kullanılmamış olduğundan yaka kısmı kapalıdır ve süslemesi bulunmamaktadır. Koca ve Komanlar ile Abanoz ve diğerlerinin inceledikleri; kullanılmamış iç göynek ile benzer özellikte oldukları belirlenmiştir. Faridovna Fayzullina'nın çalışması, iç giyim olarak göynek modelini destekler niteliktedir; İtil Bulgar kadınlarının iç giysileri genelde tunik formatında gömleklerden oluşmuştur. Aslında çok eski zamanlardan itibaren Orta İtil boyunca kadınlar iç giysi olarak tunik seklinde gömlekleri tercih etmişlerdir (Faridovna Fayzullina, 2002: 82-88'den aktaran; Akıncı 2018: 84).

\subsection{Urba donu (Şalvar)}

Urba ve bürümcük iç göynek ile birlikte ve göynek etek uçları şalvarın içinde kalacak şekilde giyilirdi. Özel gün giysisi, gelinliğin alt parçası olarak kullanılırdı. 68 yıllıktır (Kaynak Kişi: Aydın, 2012).

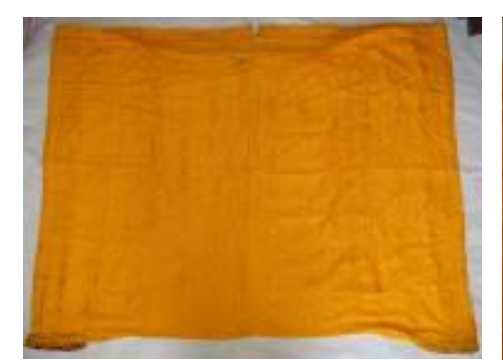

Resim 6. Şalvar (a) Ön görünümü.

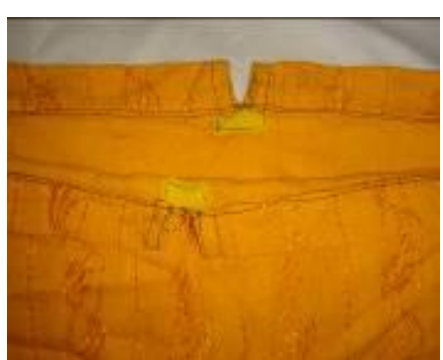

(b) Uçkurluk görünümü.

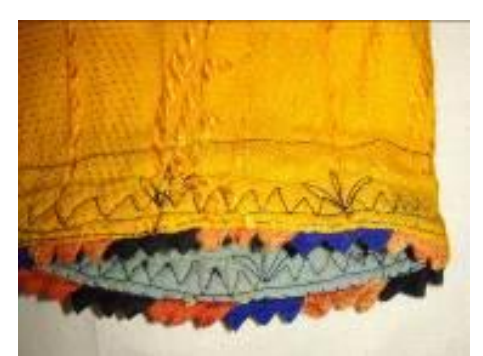

(c) Paça detay görünümü.

Alpaka (kendinden desenli) jakarlı turuncu kumaş, süslemesinde siyah, mavi, turuncu kumaşlar ve siyah dikiş ipliği kullanılmıştır. Boyu ayak bileğinde, beli uçkurlu, bol kesim, hafif ağ oyuntulu, uçkurluk ön ve arka ortası yırtmaçlı çalışılmıştır. Kumaş eni (ön-arka ve iki yanlar olmak üzere) dört en kullanılmıştır. Makinede ve elde çırpma dikişi tekniği ile dikilmiştir. Elde ve makinede süsleme 
dikişi yapılmıştır. Kumaş parçaları üçgen (muska) şeklinde hazırlanıp paçaların uçları pervaz ile tutturulmuştur.

\subsection{Urba donu (Şalvar)}

Urba ve bürümcük iç göynek ile birlikte ve göynek etek uçları şalvarın içinde kalacak şekilde giyilirdi. Özel gün giysisi, gelinliğin alt parçası olarak kullanılırdı.

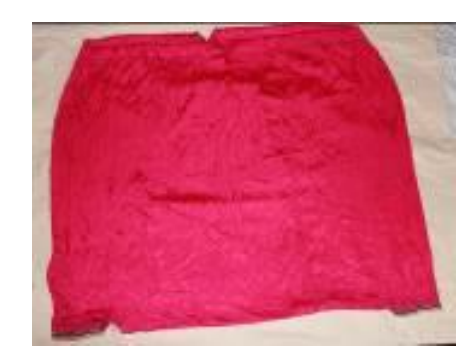

Resim 7. Şalvar (a) Ön görünümü.

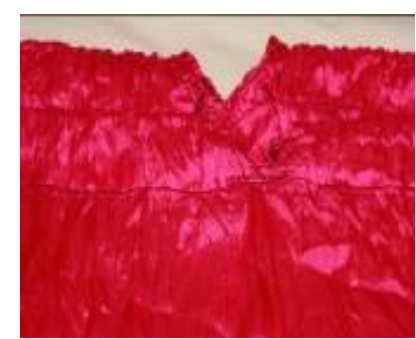

(b) Uçkurluk görünümü.

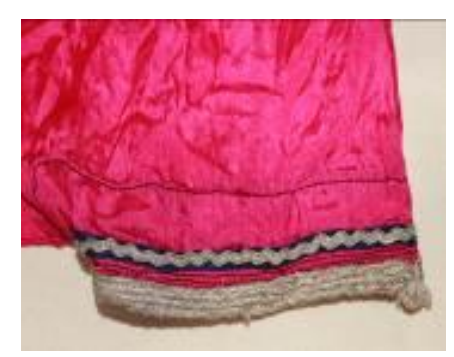

(c) Paça detay görünümü.

Pembe Mariken (ipek), süslemesinde siyah kumaş şerit, balıksırtı ve sutaşı harç, dikiminde siyah dikiş ipliği kullanılmıştır. Boyu ayak bileğinde, beli uçkurlu, bol kesim, hafif ağ oyuntulu, uçkurluk ön ve arka ortası yırtmaçlı çalışılmıştır. Kumaş eni (ön-arka ve yanlar) olarak dört en kullanılmıştır. Makinede dikilmiştir. Siyah şerit kumaşların üzerine sutaşı yerleştirilerek dikilmiş ve paçaların uç kısmına balıksırtı harçlar tutturularak süslenmiştir.

\subsection{Urba donu (Şalvar)}

Urba ve bürümcük iç göynek ile birlikte ve göynek etek uçları şalvarın içinde kalacak şekilde giyilirdi. Özel gün giysisi, gelinliğin alt parçası olarak kullanılırdı.

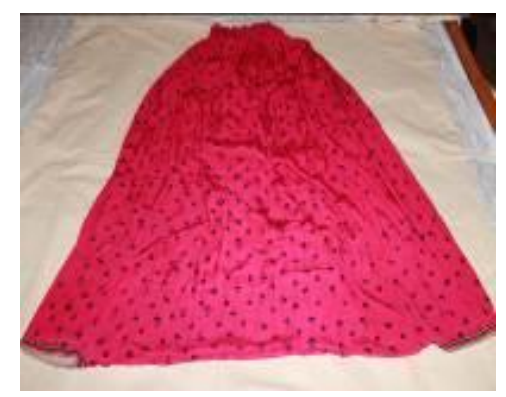

Resim 8. Urba donu-Şalvar.

Kırmızı üzerine siyah desenli ipek kumaş, süslemesinde siyah kumaş şerit, balıksırtı harç ve sutaşı, dikiminde siyah dikiş ipliği kullanılmıştır. Boyu ayak bileğinde, beli lastikli, bol kesim, hafif ăg oyuntulu çalışılmıştır. Kumaş eni olarak (ön-arka ve yanlar) dört en kullanılmıştır. Makinede dikilmiştir. Paça süslemesinde siyah şerit kumaşların üzerine sutaşı ve paçaların uç kısmına balıksırtı harçlar tutturularak süslemesi tamamlanmıştır.

Koca ve Komanlar (2019) İzmit Balkan Kültür Evi'nde Sergilenen Bulgaristan Göçmeni Kadın şalvarlarını incelemiş; mor renkli, kendinden yaprak ve çiçek deseni olan jakarlı ipek kumaştan üretilmiş, ve şalvarın geniş ağ kesim olduğunu belirlemişlerdir (Koca-Komanlar 2019: 939). Bununla birlikte, Eskişehir'de yaşayan Bulgaristanlı göçmen kadınlara ait giysiler arasındaki şalvarların geniş, düşük ağlı (ayak bileğinin $10 \mathrm{~cm}$ üstünde) olduğunu ve 3,5 metrelik malzemeden kesilmiş olduklarını ve genel olarak tüm giysilerin basit desenleri olduğu tespit edilmiştir (Boğday, vd. 2014:134). 


\section{Al-Farabi International Journal on Social Sciences}

\subsection{Futa (Önlük)}

Evli kadınlar dış giysi üzerine gündelik ve aynı zamanda gezmeye giderken de takarlardı. 88 yıllıktır (Kaynak Kişi: Aydın, 2012).

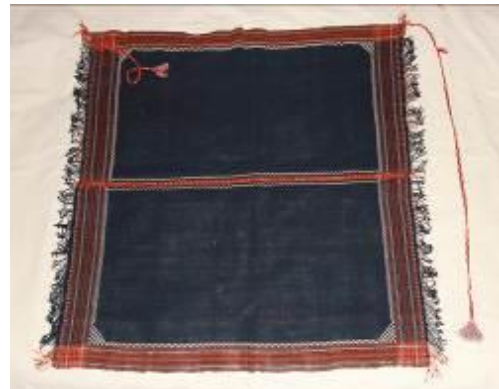

Resim 9. Futa (a) Ön görünüm.

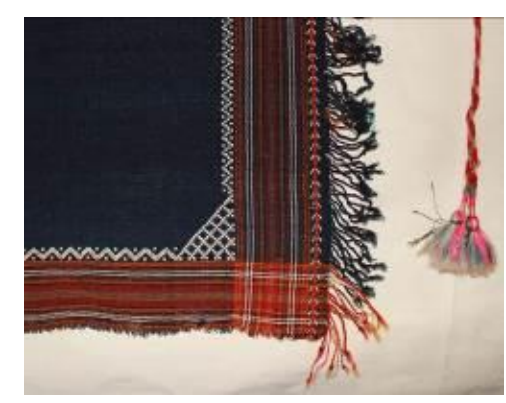

(b) Süsleme detayı görünümü.

Bezayağı dokuma olarak yünden, çufallık adı verilen el tezgâhında dokunmuştur. Lacivert, turuncu, krem, bordo, yeșil renkler kullanılmıștır. Dar dokuma olduğu için iki parçadan dikdörtgen oluşturularak tasarlanmıştır. İki parça birbirine elde sarma ve ajur ile tutturulmuştur. Elde renkli iplerle saç örgüsü yapılarak uçkur, bağcık çalışılmış ve ucuna püskül yapılmıştır. Futanın iki kenarından ipler çekilerek oluşturulan püskül ile süslenmiştir.

Koca ve Komanlar (2019) Bulgaristan göçmeni kadın giyiminin önemli tamamlayıcı parçalarından biri olan önlük için bazı kesimlerin "fita" ismini kullandıklarını belirtmişlerdir (Koca- Komanlar, 2019: 938). İnceledikleri Fita ismindeki önlüğün Resim 9'daki futa ile benzer özelliklere sahip olduğu saptanmıştır.

\subsection{Gocuk (Hırka)}

Gezmeye giderken üst giysisi olarak kullanılırdı. 66 yıllıktır (Kaynak Kişi: Cebeci, 2012).

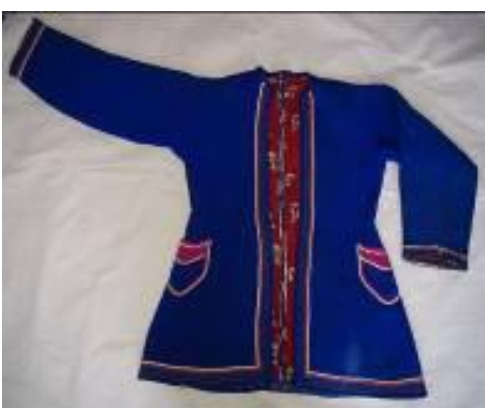

Resim 10. Gocuk (a) Ön görünümü.

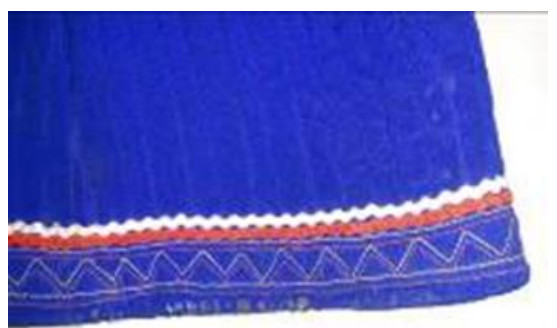

Resim 11. Gocuk (a) Süsleme detay görünüm

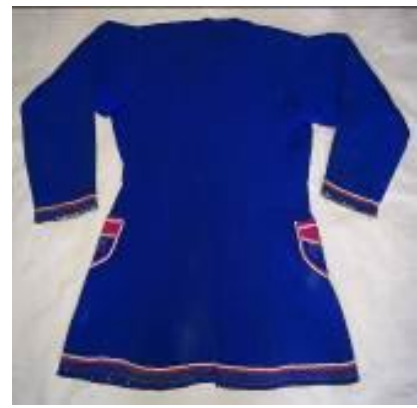

(b) Arka görünümü.

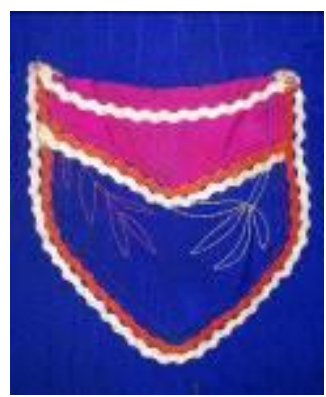

(b) Cep.

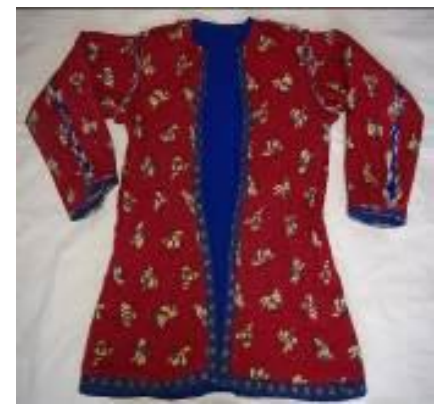

(c) Astar görünümü.

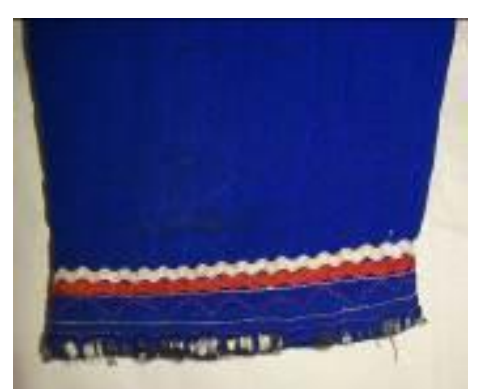

(c) Kol detay görünümü. 
Koyu mavi ipek (mariken) kumaş, ara dolgusu olarak pamuk, astar olarak kırmızı emprime desenli baskılı pamuklu kumaş, ön ortası kenarlarında lacivert desenli şerit kumaş, süslemesinde pembe pamuklu kumaş, krem, kırmızı, lacivert iplik, beyaz ve kırmızı sutaşı kullanılmıştır. Giysinin boyu; kalçanın altında, ön ve yanlar pensli, uzun takma kollu, sıfır yaka, sıfır kapama, arkası kuplu, yanı dikişsiz, ön arkaya kaydırılarak kup oluşturulmuş, aplike cepli olarak tasarlanmıştır. Makinede (kollu el makinesi ile) dikilmiştir. Giysi dubleleme tekniği ile astarlanmıştır. Tüm beden makine dikişi ile kapitone yapılmış, ön ortası, kol ucu ve etek ucu, aplike cep kenarlarına sutaşı ve renkli ipliklerle geometrik ve bitkisel bezemelerle kapitone dikişi çekilerek, cep ağzı pembe kumaş ile temizlenerek süslenmiştir.

\subsection{Gocuk (Hurka)}

Gezmeye giderken üst giysisi olarak kullanılırdı. 87 yıllıktır (Kaynak Kişi: Albayrak, 2012).

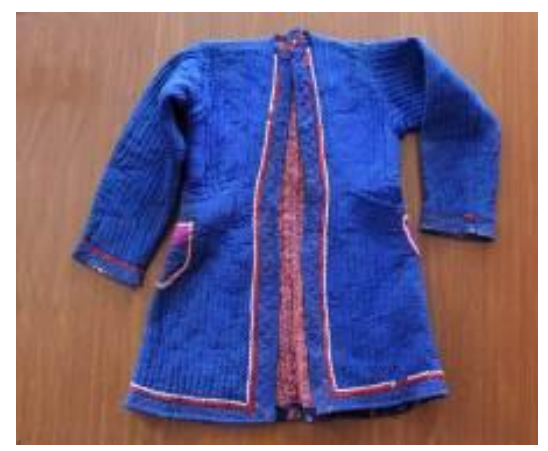

Resim 12. Gocuk (a) Ön görünüm.

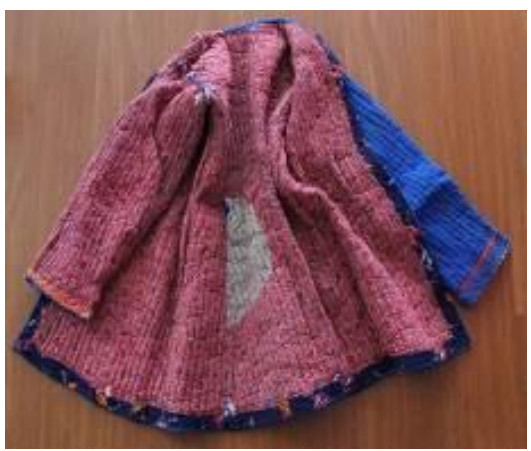

Resim 13. Gocuk (a) Astar görünümü.

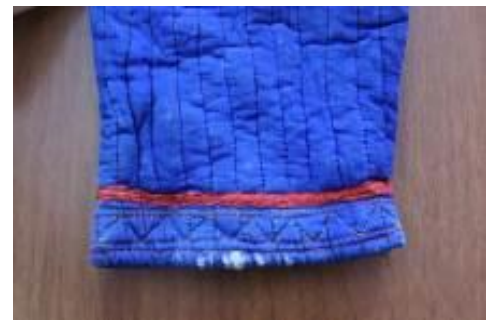

Resim 14. Gocuk (a) Kol ucu detay görünümü.

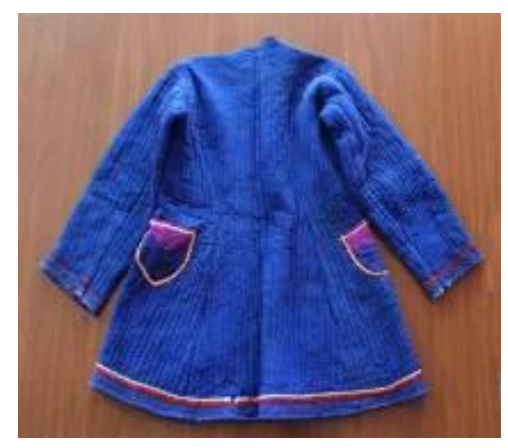

(b) Arka görünümü.

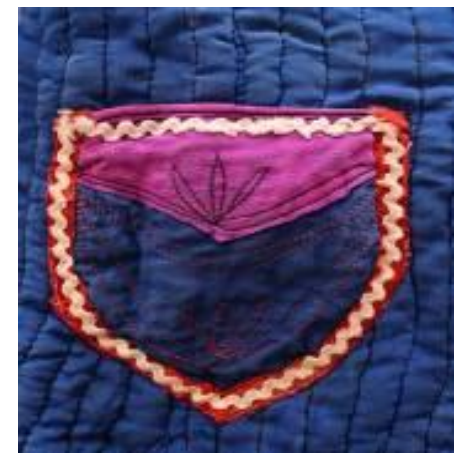

(b) Cep görünümü.

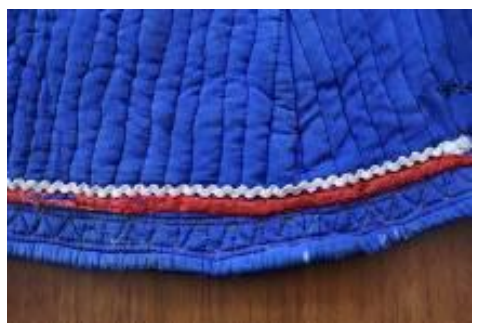

(b) Etek ucu görünümü.

Koyu mavi ipek kumaş (mariken), ara dolgusu olarak pamuk, astar olarak emprime desenli koyu pembe baskılı pamuklu kumaş, ön ortası iç kenarlarında lacivert desenli şerit kumaş, süslemesinde pembe ve kırmızı pamuklu kumaş, krem, kırmızı, lacivert iplik, beyaz sutaşı kullanılmıştır. Giysinin boyu; kalçanın altında, ön ve yanlar pensli, uzun takma kollu, sıfır yaka, sıfır kapama, arkası kuplu, yanı dikişsiz, ön arkaya kaydırılarak kup oluşturulmuş, aplike cepli olarak tasarlanmıştır. Makinede dikilmiştir. Emprime desenli (baskılı) koyu pembe pamuklu kumaş makinede dikildikten sonra, 
bedene elde tutturularak astarlanmıştır. Yıpranan yerler farklı kumaş ile onarılmıştır. Tüm beden makine dikişi ile kapitone yapılmıştır. Ön ortası, kol ucu, etek ucu ve aplike cep kenarlarına kırmızı şerit kumaş üzerine sutaşı dikilmiştir. Renkli ipliklerle geometrik ve bitkisel bezemelerle kapitone çekilerek, cep ağzı koyu pembe kumaş ile temizlenerek süslenmiştir.

İncelenen iki örneğinde neredeyse birbirinin aynısı olduğu görülmektedir. Koca ve Komanlar (2019) yaptıkları araştırmada gocuk "ceket "olarak isimlendirilmiş olmakla birlikte, örneklerden biri hem renk olarak, ikisi de model, kesim, dikim ve süsleme olarak benzer özellikler göstermektedir. Tek farklılık kol altında kuş parçalarının olmaması ve süslemelerinin farklı olmasıdır.

\subsection{Ferece - Ferace}

Dış giysisi olarak (manto- pardösüsü gibi) giyilirdi. 98 yıllıktır (Kaynak Kişi: Şahin, 2012). Düzce ili Hasanağa köyünde de dış, giysi olarak tüm kadınlar tarafından sokağa çıkarken kullanılmıştır. Günümüzde hala üst giysisi olarak giyilmekle birlikte kara çarşaf olarak isimlendirilmektedir (Abanoz, vd. 2016: 204-205).

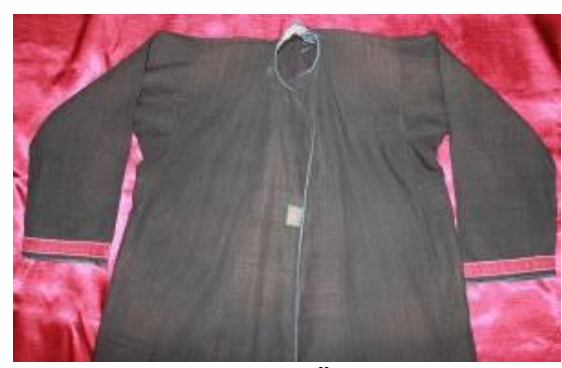

Resim 15. Ferace Ön görünümü.

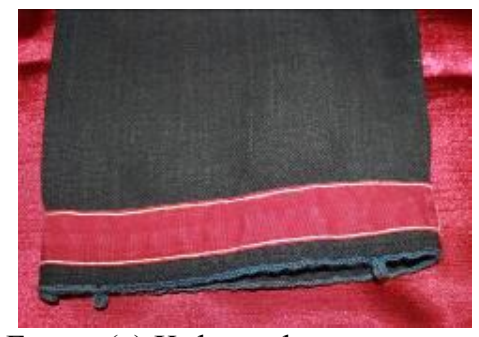

Resim 16. Ferace (a) Kol ucu detay.

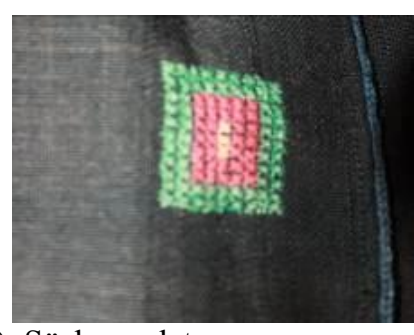

(b) Süsleme detay.

Feracede Yün (Eriş) siyah ve kırmızı kumaş, mavi, siyah, sarı, yeşil ip, mavi ince kordon kullanılmıştır. Giysi boyu uzun bileğe yakın, sıfır yakalı, kare uzun takma kollu, yanları peşli, koltuk altı kuşlu, kruvaze kapamalıdır. Makinede ve elde dikilmiştir. Yaka farklı kumaşla pervaz çalışılarak temizlenmiştir. Ön ortasında bel hizasında kare şeklinde kanaviçe işleme yapılmıştır. Kol ağzı kırmızı kumaş bant ile kol ucu, ön ortası ve yaka kenarı mavi renk iplikle zincir çekilerek hazırlanan kordon ile süslenmiştir.

\subsection{Ferece- Ferace}

Kadın dış giysisi olarak giyilirdi. 108 yıllıktır (Kaynak Kişi: Çalışkan, 2012). 


\section{Al-Farabi International Journal on Social Sciences}

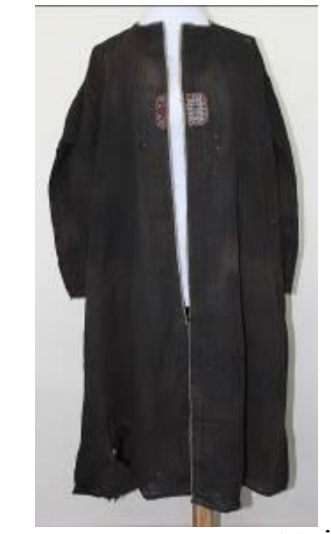

Resim 17. Ferace (a) Ön görünümü.

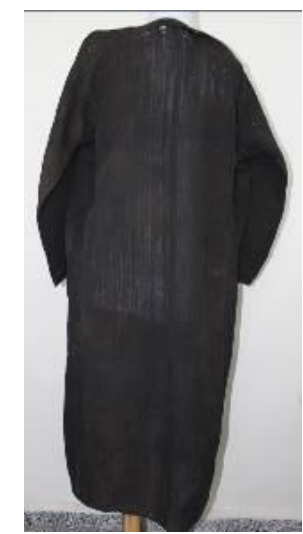

(b) Arka görünümü.
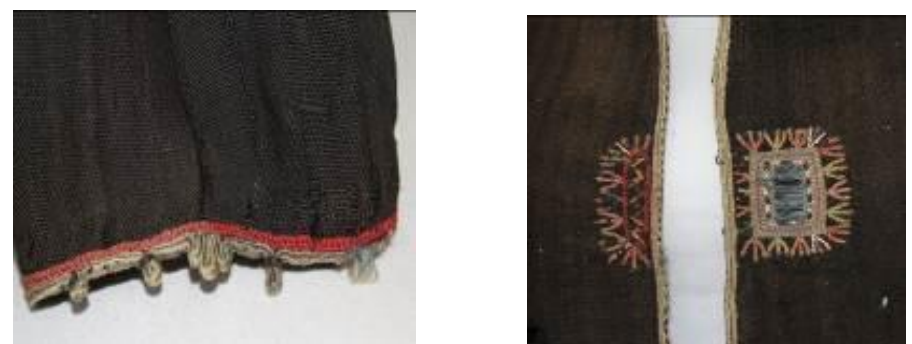

Resim 18. Ferace (a) Kol ucu süsleme detay görünümü. (b) Ön süsleme detay görünümü.
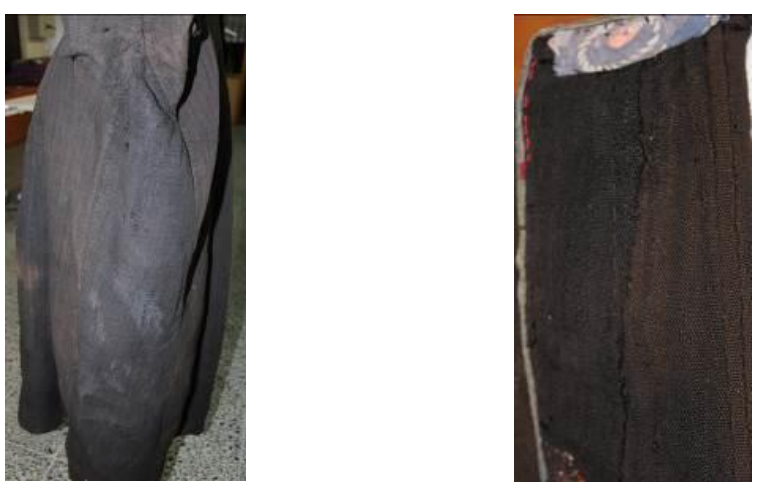

Resim 98. Ferace (a) Yan peş kol altı detay görünümü. (b) İç yaka pervaz detay görünümü.

Ferace; yün (Eriş) siyah ve karışık desenli kumaş, krem rengi, siyah, kırmızı, ip kullanılmıştır. Giysi boyu uzun, diz altında, sıfır yakalı, sıfır kapama, kare uzun takma kollu, yanları peşli ve kuşlu tasarlanmıştır. Giysi elde oyulgama ve çırpma dikişi tekniği kullanılarak dikilmiştir. Yakası desenli kumaş kullanılarak pervazla temizlenmiştir. Zincir işi ve elde makine dikişi tekniği kullanılarak ön ortasında beden hattı hizasında dikdörtgen süsleme yapılmıştır. Kol ağzı kırmızı, krem renkli, yaka ve ön ortası krem rengi iplikle zincir çekilerek hazırlanan kordon ile tutturularak süslenmiştir.

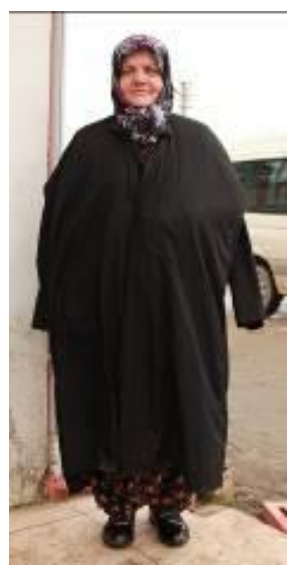

Resim 20. Feracenin giyim şekli. 
Saritaş ve diğerlerinin (2007), Balıkesir ve çevresinde yapmış oldukları araştırmada, merkez ve çevre köylerinde giyilen feracenin kadınlar arasında kabul gören tek renginin siyah olduğu, üzerlerinde desen ve süsün bulunmadığı tespit edilmiştir (Sarıtaş, vd. 2007: 200-202). Düzce ili Selamlar köyünde de durum aynıdır. Kara Çarşaf olarak isimlendirilen dış giysinin farkı; ipek kumaştan yapılmış olması, üst ve alt olarak iki parçadan oluşması, belden dikişli ve lastikli, üst parçası belden itibaren omuzları kapatarak, başı da örtmesidir (Abanoz, vd. 2013: 83).

\subsection{Grep (Başörtüsü)}

Genç kızlar başlarını grep ile pelik altı şeklinde (başın arkasından, enseden) bağlayarak kullanırlardı. 68 yıllıktır (Kaynak Kişi: Şahin, 2012).

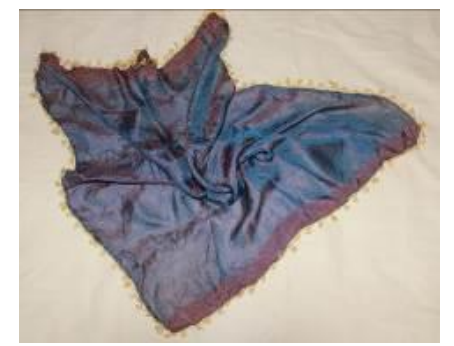

Resim 21. (a) Mor grep.

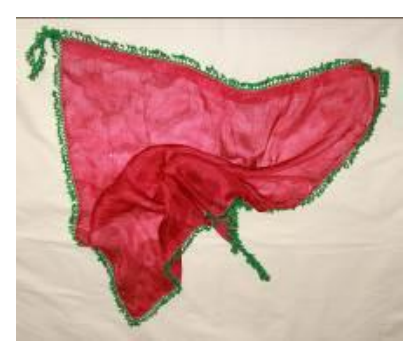

(b) Kırmızı grep.

Mor ve kırmızı ipek kumaş, sarı, yeşil kuka iplik ve pul kullanılmıştır. Kare hazırlanan mor grep; kenarları sarı renk ip ile mekik oyalı, kare hazırlanan kırmızı grep; yeşil renkli ip ile pullu tı̆̆ oyası ile süslenmiştir. Abanoz ve diğerlerinin araştırmasında Düzce ili Yeni Taşköprü köyünde sarı ve bordo ipek kumaştan, kare, mavi, kırmızı, krem ve sarı kuka iplikle, yelpaze ve badem deseninde iğne oyalı iki grep incelenmiştir. Greplerin ortak özelliği ipek kumaş kullanılması, parlak ve canlı renklerinin olmasıdır.

\subsection{4. Çember}

Genç ve yaşlı bütün kadınların kullandığı başörtüsüdür. Genç kızlar başlarını pelik altı (başın arkasından, enseden), evli kadınlar gıdık altı (önden) bağlarlardı. 66 yıllıktır (Kaynak Kişi: Şahin, 2012).

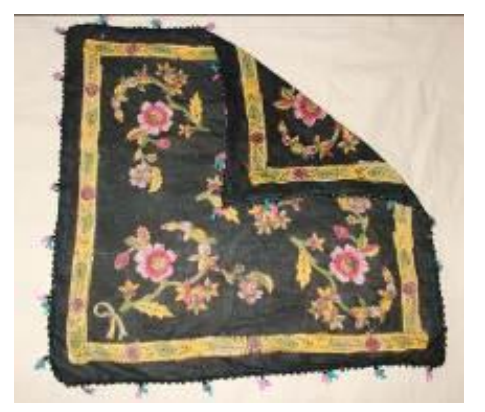

Resim 22. Çember.

Yaprak, dal, çiçek desen baskı1ı 73x73 kare olan çemberin kenarları pembe ve mavi yumak ip kullanılarak iğne oyası ile süslenmiştir. 


\section{Al-Farabi International Journal on Social Sciences}

\subsection{5. Çorap ve çetik}

Yün iplik eğrilerek elde örme kadın çorabıdır (Selamlar Köyü Müzesi, 2012).

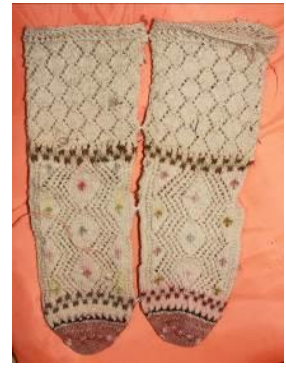

Resim 23. Desenli, Ajurlu kadın çorabı.

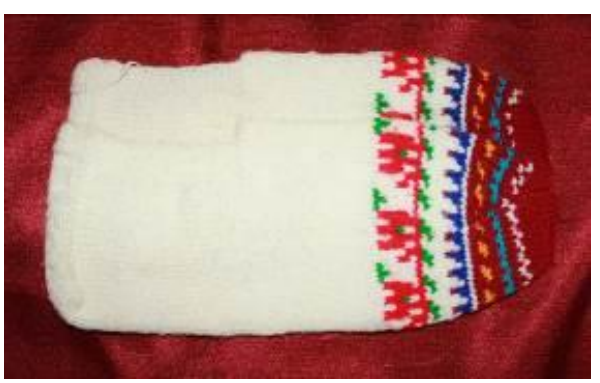

Resim 24. Elde örülmüş çetik

Çorapta krem renkli yün iplik, süslemesinde kırmızı, mavi, yeşil, kahverengi, siyah, pembe renkli iplikler kullanılmıştır. Kısa konçlu, elde beş şiş ile örülmüştür. Renkli iplikler kullanılarak desen oluşturulmuş ve ajur ile süslenmiştir. Çetik ise yine elde beş şiş ile örülmüş, burun kısmında sekiz farklı renk kullanılarak desen verilmiştir.

Bulgar göçmeni kadınların ayaklarına elde yünden örülmüş, çorap ve çetik giydikleri, her ikisinin de burun, topuk ve bilek kısımlarında değişik motiflerle süsleme yaparak ördükleri tespit edilmiştir (Koca-Komanlar 2019: 938).

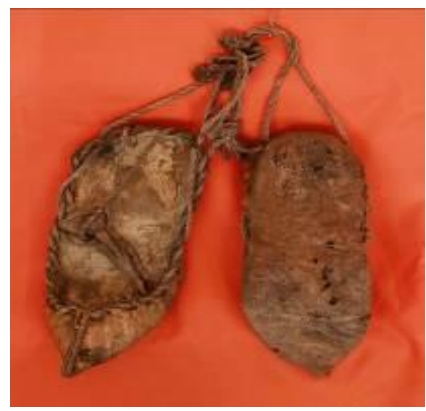

Resim 25. Deriden yapılmış çarık (Selamlar Köyü Müzesi, 2012).

Düzce ili Gümüşova ilçesi, Selamlar Köyü Atatürk müzesinde sergilenen Bulgar göçmenlerine ait çarık; deriden yapılmış olup, kenarları ipliklerle bağlanmıştır.

Deri zanaat üretimi oldukça gelişmiş olan İtil Bulgarlarının tercih etmiş, olduğu ayakkabıların başında deri gelmiştir. Ayakkabı olarak hafif topuksuz, dizlere kadar olan çizmeler, iplerle dikilen, iki ya da tek parça deriden imal edilen deri çarıklar (tapoçki) tercih edilmiştir (Rudenko, 2018:152'den aktaran; Akınc1, 2018: 86). 


\section{Al-Farabi International Journal on Social Sciences}

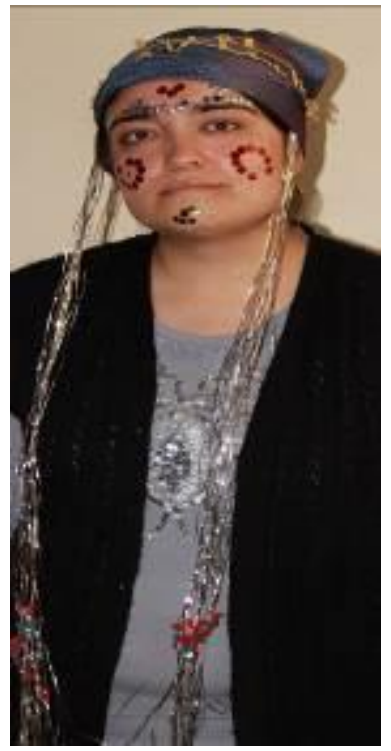

Resim 26. Muhacirlerde gelin yüzünün süslenmesi.

Gelinin yüzü, renkli pullar kullanılarak, çeşitli desenlerle süslenirdi. Yapıştırıcı olarak yumurtanın beyazı kullanılırdı. Gelinin duvağına uzun parlak teller takılırdı (Kaynak Kiși: Albayrak, 2012). Osmanlı gelin başı süslemelerinde; gelin teli denilen ince, uzun gümüş, telin başlığa tutturulduğu üzerine ise kırmızı duvak örtüldüğü bilinmektedir (Aktepe-Erol 2019:340). Osmanlı'nın bir parçası olan Bulgar göçmenlerinde de gelin başı süslemede gelin teli adı verilen, uzun parlak tellerin kullanıldı̆̆ı saptanmıştır.

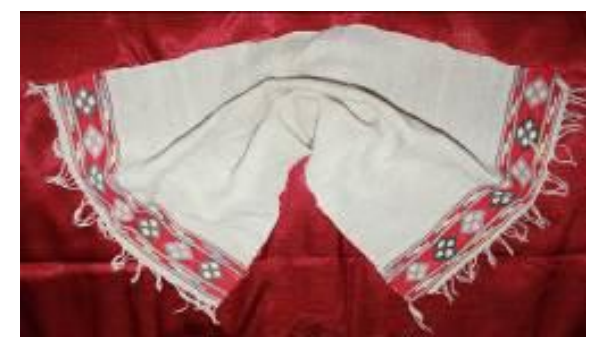

Resim 27. (a) Peşkir.

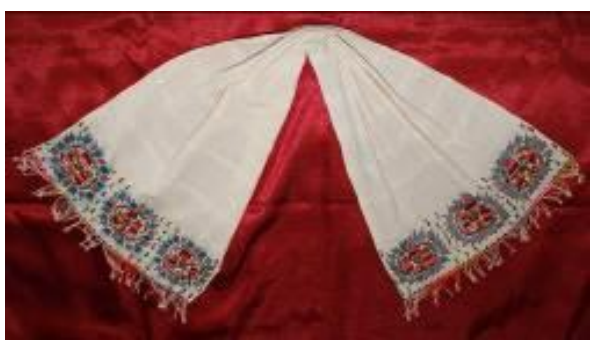

(b) Peşkir 65 yıllık.

Peşkirler, bezayağı pamuklu dokuma beyaz/krem kumaş kullanılarak dikdörtgen şeklinde yapılmış, iki kenarın da nakışlı ve püsküllü tasarlanmıştır.

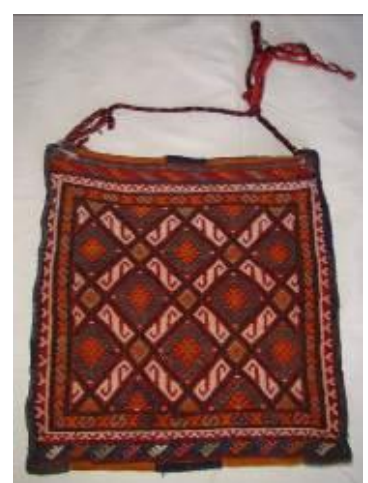

Resim 28. (a) Heybe- çanta.

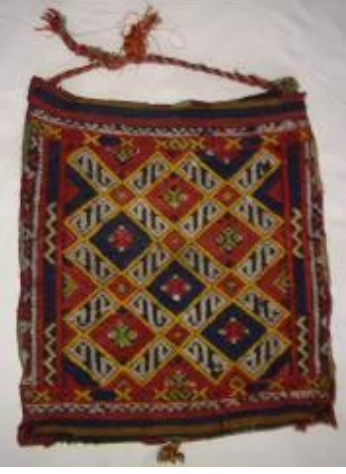

(b) Heybe- çanta 80 yıllıktır. 
Heybeler; Kilim deseni verilerek el tezgahında dokunmuşlardır. İki heybede de kare, dikdörtgen (geometrik)desenler ön plandadır. Heybelerin askılıkları yün ipliklerden bükülerek hazırlanmış olup kenarları battaniye iğnesi tekniği ile yine yün iplikle birleştirilmiştir. Koca ve Komanlar (2019) çalışmalarındaki heybelerin aksine bu heybelerde, şu taşı kullanılmamıştır. Süslemesinde sadece kilim desenleri ön plana çıkmaktadır. Ve kenarlarında saçak bulunmamaktadır. Bunların dışında diğer özellikleri benzerlik göstermektedir (Koca-Komanlar 2019: 937).
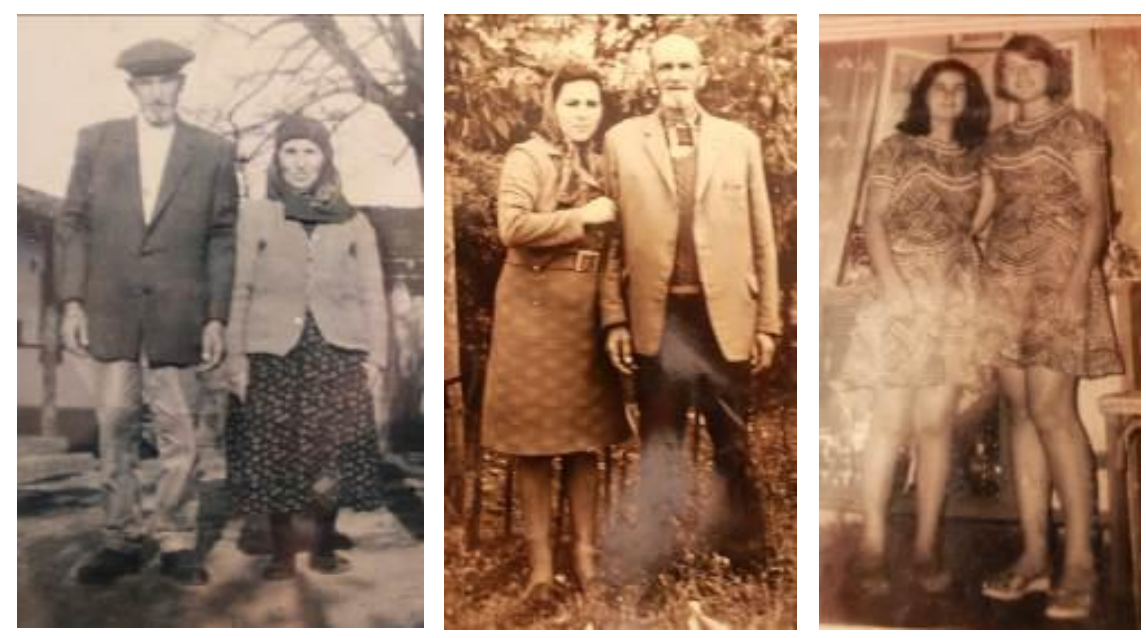

Resim 29. Eski fotoğraflar (Kadın ve erkek kıyafetleri-1970).

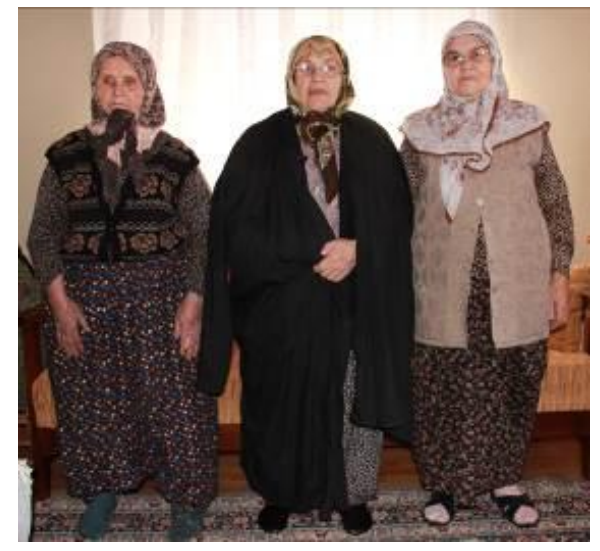

Resim 30. Yaşlı kadınların giydiği günümüz kıyafetleri

Resimde görüldüğü üzere urba donu (şalvar), çember (başörtüsü) ve ferace kullanımı hala Düzce ili Gümüşova ilçesi Selamlar köyünde devam etmektedir.

\section{Sonuç}

Bugün sayıları giderek azalan geleneksel giysiler; hazır giyim sektöründeki gelişmeler, basın yayın organları, teknoloji, yaşam koşulları gibi pek çok sebeple eski anlam ve önemini yitirmiş, hızla yok olma tehlikesi ile karşı karşıya kalmıştır. Toplumun kültürünü gelenek ve göreneklerini yaşam biçimini simgeleyen ve tanıtan geleneksel giysilerin incelenmesi ve belgelenmesi gelecek kuşaklara tanıtılması açısından büyük önem taşımaktadır. 
Düzce İli Gümüşova İlçesi Bulgaristan göçmenlerinin yaşadığı Selamlar köyü geleneklerine, tarihine ve kültürüne bağlı bir köy olarak geleneksel kıyafetlerini kendi kurmuş oldukları müzede saklayarak bu konuda ne kadar duyarlı olduklarını ortaya koymuş ender köylerden biridir.

Türk giyim kuşam kültürü içinde hem erkek hem de kadın için önemli bir parça olan şalvarın, Bulgaristan Türkleri içinde önemli bir giysi olduğu görülmektedir.

Urba ve yelek altında iç göynek, urba donu iç göyneğin üzerinde kalacak şekilde giyilen ve başa grep başörtüsü takılarak oluşturulan özel gün kıyafeti olduğu, gocuk ve feracenin dişarı çıkarken, gezmeye giderken giyilen diş giysisi olduğu saptanmıştır.

Feracenin farklı kaynaklarda kara çarşaf olarak isimlendirildiği ve günümüzde hala kullanılmakta olduğu saptanmıştır.

Urba ve yeleğin birlikte giyilebildiği gibi ayrı olarak ta iç göynek üzerine giyilebildiği belirlenmiştir.

Araştırma sonucunda incelenen giysilerden aşağıdaki sonuçlara ulaşılmıştır;

Giysilerde kullanılan kumaşlar da canlı renklerin tercih edildiği, "mariken” denilen ipek kumaşların kullanıldığı, urba boyunun göğüs altında, sıfır yakalı ve sıfır kapamalı olduğu, üçü bedende ikisi kemerde olmak üzere beş adet birit ilik ve düğme kullanıldığı, farklı renkli astarla dublelendiği ve makinada dikildiği belirlenmiştir.

Giysilerin süslemelerinde; renkli kumaş şeritlerin elde oyulgama tekniği kullanılarak ön ortasına, kemere, manşete ve paçaya üzeri simli sutaşı ve renkli iplerle tutturulduğu saptanmıştır.

Bürümcük gömleklerin, pamuklu krem renginde, bez ayağı dar dokumadan yapıldığı, sıfır yaka ve ön ortasında derin yaka yırtmacı kullanıldı ̆̆ı, dar dokuma olmasından dolayı bedenin dört en, kolun iki en olarak çalışıldığ 1 belirlenmiştir.

Gocuklarda ipek (mariken) kumaş, ara dolgusu olarak pamuk kullanılmış, astar olarak pamuklu desenli kumaş kullanılmıştır. Gocukların boyu; kalçanın altında, ön ve yanlar pensli, uzun takma kollu, sıfır yaka, sıfır kapama, arkası kuplu, yanı dikişsiz, ön arkaya kaydırılarak kup oluşturulduğu, aplike cepli tasarlandı̆̆

Gocuk dubleleme tekniği ile astarlanmış, tüm beden kapitone yapılmıştır. Ön ortası, kol ucu, etek ucu ve aplike cep kenarlarına (sutaş1- renkli ipliklerle) geometrik ve bitkisel bezemelerle süslemeler yapıldı̆̆ı saptanmıştır.

Feracelerde kışın yünlü, yazın ince pamuklu kumaşlar kullanılmıştır. Giysi boyu uzun, diz altında, sıfır yakalı, sıfır ve kruvaze kapamalı, kare uzun takma kollu, yanları peşli ve kuşlu olarak tasarlanmıştır. Süslemesinde ise hazır kordonlar, elde zincir işi ve kanaviçe yapılarak, ön ortası, kol ucuna süsleme yapıldığı belirlenmiştir. Kullanılan feracelerin ortak özelliklerinden biri de üzerlerinde çok fazla süsün bulunmamasıdır. Genel olarak düz, siyah biçimlerine rastlanılmıştır.

\section{KAYNAKÇA}

Abanoz, G., Dursun Çalışan, Ç. ve Dursun F. (2013). Düzce İli Yeni Taşköprü Köyü Muhacir Köyü Geleneksel Kadın Giysilerinin İncelenmesi. 2. Yöresel Ürünler Sempozyumu Ve Uluslararası Kültür Sanat Etkinlikleri, Antalya,73-84.

Abanoz G., Dursun Çalışan Ç. ve Dursun F. (2016). Düzce İli Hasanağa Köyü (Muhacir) Geleneksel Kadın Giysilerinin İncelenmesi, Düzce De Tarih Kültür Ve Sanat, Düzce Belediyesi Yayınları Düzce Araştırmaları:4, Editör: Prof. Dr. Yusuf Oğuzoğlu, Yrd. Doç. Dr. Fatih Özçelik, Basım Sayısı:1, Isbn:978-605-4133-06-2.

Aktepe, Ş.ve Erol, E. (2019). Osmanlı Dönemi Gelinlikleri Ve Gelin Başlıkları, The Journal Of Social Science, Y11:3, Cilt:3, Say1:5, Do1: 10.30520/Tjsosci.516782 
Alajaji, T. N. (2012). Children's Traditional Costumes İn Najd Bedouın Settlement Areas İn The Kingdom Of Saudi Arabia Academic Research International 3(2): 516-529.

Anonim. (2018). "Düzce Gümüşova Selamlar Köyü Tanıtım Filmi” Https://Www.Youtube.Com/Watch?V=Jk9vfa4xguc, (18. Haziran 2018).

Arafat M. (2000). “Bulgaristan'daki Türk Azınlığın Türkiye’ye Göçü”. Trakya Üniversitesi Dergisi, $1(1)$.

Artun, E. (2006). “Adana Ve Osmaniye Halk Kültüründe Giyim- Kuşam Geleneği”, Halk Kültüründe Giyim- Kuşam Ve Süslenme Uluslararası Sempozyumu, 15-17 Aralık 2006.

Aydın, Ö. (2011). “Anadolu'da Giyim Kültürü”, Http://Www.İdesanat.Com/İmages/Upload/Su8402, (06.06.2018).

Ayhan, F. (2013). “Türk Giyim Kültüründe Pantolonun Gelişimi Ve Dünya Giyim Kültürüne Etkisi”, Akademik Bakış Dergisi, (37):1-13.

Bakır, S. (1999). Tokat Yöresi Giyiminin Genel Olarak İncelenmesi, İtü. Sosyal Bilimler Enstitüsü, Yayımlanmamış Yüksek Lisans Tezi, Danışman: Yrd. Doç. Dr. Göktan Ay, İstanbul.

Boğday, S., Başak, Y. ve Artaç, B. (2014). Traditional Women's Apparels Of Bulgarian Immigrants Living In Eskişehir, International Journal Of Science Culture And Sport, 2(2), Doi: 10.14486/Ijscs69

Bayraktar, Z. (2014). Geleneğin Aktarımında Ve Yaşatılmasında Göçmen Sivil Toplum Kuruluşlarının Rolü: İzmir Bosna Sancak Kültür Ve Yardımlaşma Derneği Örneği. Türük Dil, Edebiyat Ve Halkbilimi Araştırmaları Dergisi, 3:193-206.

Cebeci, A. (1970). "Bulgaristan'da İslam Dinine Yapılan Baskı”, Türk Kültürü Dergisi, 87: 209-210. Enninger, W. (1998). “Giyim”, Çev. Dr. Nebi Özdemir, Milli Folklor, 39: 92-96.

Faridovna Fayzullina D. (2002). "Jenskiy Maklaşeyevskiy Koctyum: Rekonstruktsiya İ Semantika", Problemı Drevney I Srednevekovoy İstorii Srednego Povolj'ya, Materialı Vtorıh Halikovskih Çteniy, Kazan, S. 82-88. Aktaran; Akıncı M. (2018). İtil Bulgar Kadınlarında Giyim-Kuşam, Takılar Ve İbn Fadlan'a Göre Sosyal Hayat, Türk Dünyası Araştırmaları TDA, 119 (234) :75-88.

Handan F. (2012). İç Anadolu Bölgesi Geleneksel Kadın Şalvarlarının Biçimsel Ve Fonksiyonel Özelliklerinin İncelenmesi, Gazi Üniversitesi Eğitim Bilimleri Enstitüsü, Yayımlanmamış Yüksek Lisans Tezi, Danışman: Doç. Dr. Emine Koca, Ankara.

Türkiye Diyanet Vakfi İslam Ansiklopedisi. (1995), "Ferace” maddesi, İstanbul: (Cilt XII.s. 349_ 350).

Kırzıoğlu, Görgünay N. (1988). “Anadolu Türkmen Kadın Giyimi”, Kültür Ve Sanat, 4 :41-44.

Koca, E. ve Komanlar, S. (2019). “İzmit Balkan Kültür Evi’nde Sergilenen Bulgaristan Göçmeni Kadın Halk Giyim Kuşamı”. İdil, 59: 932-942.

Koçu, R. E. (1967). Türk Giyim Kuşam Ve Süsleme Sözlüğü, Ankara: Sümerbank Kültür Yayınları. Koçu, R. E. (1969). Türk Giyim Kuşam Ve Süsleme Sözlüğü, Ankara: Sümerbank Kültür Yayınları.

Korkmaz, N. ve Öztürk, A. (2017). Bulgaristan Türklerinin Göç Süreci Ve Göçmenlerin Türkiye'deki İskan ve İş Gücüne Dayalı Entegrasyonu, Ankasam | Bölgesel Araştırmalar Dergisi, 1 (3): 268-289.

Köseoğlu, N. (1997). Milli Kültür ve Kimlik, İstanbul.

Nas, E. Celebilik, G. ve Demirbaş, A. (2011). “Tokat Nebi Köy Yöresel Kadın-Erkek Giyiminde Alevilikteki Üçleme, Dört Kapı-Kırk Makam Ve On İki İmam Kavramlarının Yansımaları” Türk Kültürü Ve Hacı Bektaş Velî Araştırma Dergisi, 60:245-264. 
Özel, M. (1992). Folklorik Türk Klyafetleri. Ankara Türkiye Güzel Sanatları Geliştirme Vakfı Yayınları.

Öztürk, E. (2013). “Atatürk'ün Ayran Molası Verdiği Köy” Http://Www.Sabah.Com.Tr/Yasam/ 2013 / 05 / 06 / (27 Ocak 2016).

Parla A. (2007). "İrregular Workers Or Ethnic Kin? Post-1990s Labour Migration From Bulgaria To Turkey”. International Migration, 45 (3) :157-181.

Tansuğ, S. (1997). “Anadolu Giysileri”. Antik \& Dekor Dergisi, 39:106-108.

Türkoğlu, S. (2002). Tarih Boyunca Anadolu'da Giyim Kuşam, İstanbul.

Sarıtas, S. Türksoy, M. ve Bilen, S. (2007). Balıkesir Ve Çevresinde Geleneksel Kadın Giysisi "Ferace" Hakkında Etnoğrafik Bir Araştırma, Balıkesir Üniversitesi Sosyal Bilimler Enstitüsü Dergisi, 10 (18): 94-205.

Sevin, N. (1973). On Üç Asırlık Türk Kıyafet Tarihine Bir Bakış, İstanbul, Başbakanlık Kültür Müsteşarlığı Kültür Yayınları, Milli Eğitim Basımevi.

Sürür, A. (1983). Ege Bölgesi Kadın Klyafetleri, İstanbul: Ak Yayınları Türk Süsleme Sanatları Serisi:7, Apa Ofset Basımevi.

Rudenko, K. "Material'naya Kul'tura Bulgarskih Seliş X-Xı11 Vv.", Http://Cyвары.Pф/Ru/Content/Materialnaya-Kultura-Bulgarskih-Selishch-X-Xii-Vv Adlı Siteden 20.04.2018 Tarihinde Alınmıştır. Aktaran; Akıncı M. (2018). İtil Bulgar Kadınlarında GiyimKuşam, Takılar Ve İbn Fadlan'a Göre Sosyal Hayat, Türk Dünyası Araştırmaları Tda, 119 (234):7588.

Ünal S. ve Demir G. (2009). Göç, Kimlik Ve Aidiyet Bağlamında Türkiye'de Balkan Göçmenleri, Ulusal Sosyoloji Kongresi Bildiri Kitabı, Aydın.

Yener, E. (1955). "Eski Ankara Kadın Kıyafetleri ve Giyiniş Tarzları”, Ankara Üniversitesi Dil Ve Tarih-Coğrafya Fakültesi Dergisi, 13 (3).

\section{KAYNAK KISSTILER}

1.Burcu Albayrak, 25 yaşında- Selamlar köyü-Düzce (Gocuk)

2.Makbule Şahin, 82 yaşında- Selamlar köyü-Düzce (Yelek, Çember, Grep başörtüsü)

3.Nurten Şahin, 58 yaşında-Selamlar köyü-Düzce (Ferace)

4.Sadiye Aydın, 85 yaşında Selamlar köyü-Düzce (Urba, İç göynek, Urba donu, Futa)

5.Seviye Cebeci, 78 yaşında- Selamlar köyü-Düzce (Gocuk)

6.Zeynep Çalışkan, 45 yaşında-Selamlar köyü-Düzce (Ferace)

7.Selamlar Köyü Müzesi, Selamlar Köyü- Gümüşova, Düzce (Çorap, Çarık, Heybeler) 